\title{
Antimicrobial activity of three medicinally important plants (Berberis balochistanica, Thymus serpyllum and Salvia bucharica) of Shudden, Mazhoo Tehsil Nana Sab area, District Pishin, Balochistan-Pakistan
}

Muhammad Idrees ${ }^{1 *}$, Saeed-Ur-Rehman ${ }^{1}$, Saadullah Khan Leghari ${ }^{1}$, Mujeeb ur Rehman², Khalil Ur Rehman ${ }^{3}$, Abdul Kabir Khan Achakzai ${ }^{1}$, Bakht Zareen ${ }^{1}$, Basra Sher Zaman ${ }^{1}$ and Arifa Malik ${ }^{4}$

1. Department of Botany, University of Balochistan Quetta, Pakistan

2. Govt. Post Graduate Degree College Quetta, Pakistan

3. Govt. Post Graduate Science College Quetta, Pakistan

4. Govt. Girls Degree College Quarry Road Quetta, Pakisatn

*Corresponding author's email: idreeskhant2@gmail.com

Citation

Muhammad Idrees, Saeed-Ur-Rehman, Saadullah Khan Leghari, Mujeeb ur Rehman, Khalil Ur Rehman, Abdul Kabir Khan Achakzai, Bakht Zareen, Basra Sher Zaman and Arifa Malik. Antimicrobial activity of three medicinally important plants (Berberis balochistanica, Thymus serpyllum and Salvia bucharica) of Shudden, Mazhoo Tehsil Nana Sab area, District Pishin, Balochistan-Pakistan. Pure and Applied Biology. Vol. 11, Issue 2, pp570-576. http://dx.doi.org/10.19045/bspab.2022.110057

\begin{tabular}{llll}
\hline \hline Received: 07/06/2021 & Revised: 29/08/2021 & Accepted: 01/09/2021 & Online First: 02/09/2021 \\
\hline
\end{tabular}

\section{Abstract}

The objective of this research was to investigate the antimicrobial capability of three significant plant species i.e, Berberis balochistanica, Thymus serpyllum and Salvia bucharica. The root of $B$. balochistanica, the whole plant of T.serpylum and leaves of S.bucharica used for this research purposes at the area of Shudden, Mazhoo Tehsil Nana Sab area District Pishin, Balochistan. The topic area is fully rich by vegetation through the said three research species. The extracts of aforementioned parts of plants were subjected to agar well diffusion method. T. serpyllum plants have the high influential antimicrobial activity specially antibacterial in following bacterial strains (Escherichia coli, Staphylococcus aureus, Staphylococcus albus, Bacillus subtilis and Slmonilatyphae).The whole plant of S. bucharica also have the antibacterial activity against the different bacterial strains (S. aureus, S.t yphae, B. subtilis, E.coli and Pseudomonas aeroginosa).The roots of B.balochistanica have the antimicrobial activities especially against bacteria strains (B. subtilis, P. aeroginosa, Striptococcus pyogenes, E. coli and $S$. aureus). Resultantly, either the whole plants of T. serpyllum and leaves of S. bucharica or the roots of $B$. balochistanica, have the highly influential role against bacteria. The examination region has the bountiful number of $B$. balochistanica, $S$. bucharica and T. seripyllum which are never examined by analysts. The various parts of these previously mentioned plants have exceptionally substance of synthetics which resist the microorganisms particularly various kinds of microbes. Thus, it is inferred that the exploration plants may be conceivably utilized in numerous applications because of their antimicrobial properties.

Keywords: Antibacterial activities; Balochistan; Leaves; Medicinal plant; Roots; Seed; Stems 


\section{Introduction}

Utilization of therapeutic spices as antiquated prescription is one of the consistently utilized practices in subcontinent. Plants have consistently been a wellspring of fix to various infections because of essence of numerous phytochemical compounds [1]. Medications that are acquired from home grown sources have a striking impact in forestalling and relieving deadly illnesses. Individuals in most created nations utilize customary medication in medical services [2]. Locally, different plants are utilized as drugs at the fundamental levels in various areas of the world. Larger part of individuals is subject to natural plants for medical services [3].

Exploration by WHO on normal natural medications like gentamycine showed such meds are not sufficient against the organisms any more. There are numerous medications that were viable once yet don't show action against unsafe bacterial strains [4]. A couple of meds may in like manner have indications that reason various anomalies in the body as aside impact. These conditions frantically constrained specialists for looking for drugs which are reasonable, ensured and naturally degradable and with least results [5].

Conventional prescription assumes a critical part in the medication of created countries. Home grown plants have been utilized for a specific period as answers for human infections in light of the fact that these are therapeutically significant [6]. Cassia alata (L.) is a significant therapeutic plant local to Asian nations, particularly India and Pakistan. Particular pieces of the plant were seen to show restorative properties like antimicrobial and pain relieving. The treatment of ring worm did with the assistance of leaves of this plant. It is customarily extremely helpful against skin illnesses in man and steers [7].

Populace blast expanded the need of common assets to address the issue of food, garments medication and so forth. The utilization of ethnomedicinal information has acquired extraordinary worries in the course of recent years on account of its powerful and low or no results in contrast with allopathic medication. Other than the plants are utilized to make different life saving drugs.

Rahman et al. [8] announced the utilization of restorative plants through contemplating their clinical application by means of most recent techniques. Long scope of restorative plant parts is utilized as crude material for drugs. Not with standing, quantities of plants have been investigated for antibacterial action yet some neighborhood plants of certain spaces stay under the shell and stay neglected for the different antimicrobial potential that the nearby local area is happily using [9]. The developing issue of bacterial protection from the accessible anti-toxins has wanted to look for new antibacterial specialists.

Pishin is one of the huge urban communities of Balochistan. It is located in the Balochistan and adjecent to niegbering country Afghanistan. It covers a space of 7819 sq. km (3019 sq mile) with a height of $1400 \mathrm{~m}(4500 \mathrm{ft})$ to 1700 meters $(5500 \mathrm{ft})$ above ocean level. Pishin is among the coldest urban communities of Balochistan. The normal precipitation is recorded 15.23 $\mathrm{mm}$ in winter season and snowfall is additionally recorded in December and January. The including research area is in the peripheries of Ziarat.

B. balochistanica is an endamic shrub, and includes in Berberidaceae family which is located in the region of Quetta, Ziarat and Pishin Balochistan, Pakistan. Common name of the sp is Zralga. The roots of $B$ balochistanica are used for different diseases such as fever, wound healing, Anatomical injury, Coughing, Bone diseases as well as internal infection of human being and other animals $[10,11]$.

T. serpyllum $\mathrm{L}$. is a perennial shrub, native to regions of northern, central Europe and Asia specially Pakistan including Baluchistan area of Pishin. It is known as breckland thyme, wild thyme, or creeping thyme; however, its specific name 
"serpyllum" is derived from the Greek word meaning "to creep," because of wild thyme's trailing habit. The local name of T.serphyllum is "Morrai" It has a long stem, which is woody at the base but with a sterile leaf rosette at the top [12]. The leaves of $T$. serphyllum are used for Respiratory disorder, Illness and Asthma [11].

$S$. bucharica is aromatic shrub belongs to family Lamiaceae, contain 900 species present in all over the world and it is the largest genus of family Lamiaceae [7]. $S$. bucharica is an endemic sp of Baluchistan distributed in the region of Quetta, Loralai, Pishin. Local name is "Sursandah". It is used for lungs diseases, Heart diseases, Diarrhea, Dysmenorrheal hemorrhoids, and amenorrhea [12]. Customary medications are amount of the relative multitude of convictions, practices and information that are utilized in finding, end and anticipation of mental, physical and social awkwardness [13].

Restorative plants are utilized for microbial debasement to set up subjective items [14]. The majority of plants ere medicinal in nature in Baluchistan [15]. Baluchistan has significant verdure of medicinal plants that have remedial properties. Urbanization, Human populace, industrialization and outflow of hurtful gases is annihilating the country's regular assets. Therapeutic plants are amazing in opposing different bacterial contaminations [16].

\section{Materials and Methods Acquisition of plant tests}

The plant tests were gathered from Shudden, Mazhoo Tehsil Nana Sab Area District Pishin. These were perceived and confirmed by Prof Dr. Saeed Ur Rehman kakar, University of Balochistan, Quetta.

\section{Plants remove planning}

The gathered plant parts were cleaved into little pieces and shade dried at $32-35^{\circ} \mathrm{C}$. About 15 grams of each plant example was powdered with the assistance of an electric blender. Each example was extricated with methanol. Following 24 hours, the concentrates were separated through fine filtration with the assistance of Whatman channel paper. At that point the filtrate was moved in rotational cup evaporator, until dried [17].

\section{Test species}

Different microorganisms were utilized for the investigation that incorporates organisms and number of microbes. Such as, E. coli, S. aureus, B. subtilis, S. typhae, $P$. aeroginosa, and $S$. pyogenes, every one of the bacterial strains were filled in supplement stock and hatched at $37^{\circ} \mathrm{C}$ for in any event two days [17].

\section{Agar well dispersion strategies}

Agar well dispersion strategy was utilized to investigate antimicrobial capability of $B$. balochistanica, $T$. serpyllum and $S$. bucharica. It is a typical strategy used to test the antimicrobial action of plants separates [18].

In this cycle the outside of agar plate was tested by dispersal of volume of the microbial inoculums on the absolute surface of agar. At that point, an opening was subjected with a distance across of 6 to $8 \mathrm{~mm}$ with a cleaned stopper drill and a concentrate arrangement of volume (20$100 \mu \mathrm{L}$ ) at picked focus was filled the well. A short time later, agar plates were hatched under proper conditions relying on the organic entity being scrutinized. The counter microbial specialist was diffused in the agar medium and hindered the development of the microorganisms [19].

\section{Results}

All the research plants B. balochistanica, $S$. bucharica and $T$. serpyllum have antimicrobial activity of the selected area. Different types of chemical compound are present in aforementioned plants.

The recent information unmistakably shows that B.balochistanica roots are similarly more successful metabolites in large quantity like as phenols, against all test plant species. B. balochistanica have secondary vitamins, alkaloids, carotinoides and flavonoides [20]. The leaves of $B$. balochistanica have Due to these components shows the immense effects low effect against the Bacteria as compare to roots. B. balochistanicah as the highest 
inhibitory zone against the $S$. pyogenes which is $81 \%$ but the lowest for $P$. aerogenosa. Mean value is 26.6 Shown in (Table 1 \& Fig. 1).

Table 1. Antibacterial activity of B. balochistanica roots in Methanol extract

\begin{tabular}{|c|c|c|}
\hline Microbes & Inhibition zone(mm) & Inhibition \% \\
\hline B subtilis & $\mathbf{2 2}$ & $\mathbf{5 8}$ \\
\hline S pyogenes & $\mathbf{3 3}$ & $\mathbf{8 1}$ \\
\hline P aeroginosa & $\mathbf{1 9}$ & $\mathbf{4 2}$ \\
\hline E coli & $\mathbf{2 9}$ & $\mathbf{8 0}$ \\
\hline S aureus & $\mathbf{3 0}$ & $\mathbf{7 2}$ \\
\hline Mean & $\mathbf{2 6 . 6}$ & \\
\hline
\end{tabular}

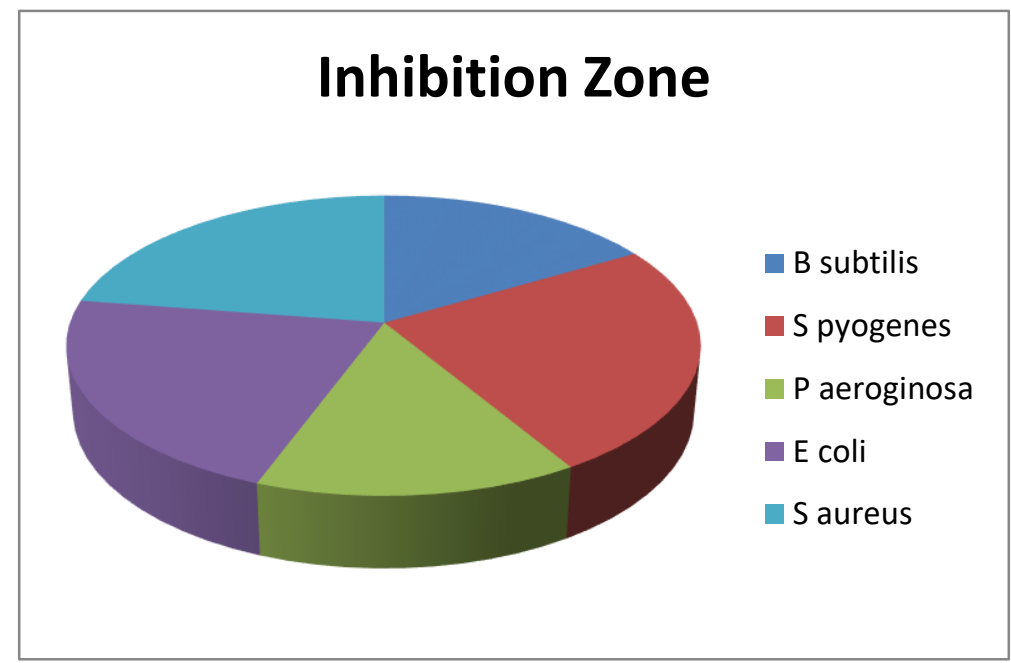

Figure 1. Inhibition zone of $B$. balochistanica

S. bucharica plants possess antimicrobial activity. Distinctive bacterial contents containing both Gram negative and Gram positive life forms were utilized for the assessment of antibacterial movement. The outcome showed that concentrates from $\mathrm{S}$. bucharica (leaves) had antibacterial action, in spite of the fact that they vary essentially in their exercises against tried miniature living beings. S. bucharica plant has the maximum inhibition zone (45\%) against the $S$. aureus and the minimum inhibition zone $(24 \%)$ against the $P$. aerogenosa. the average value is 31.4 shown in (Table $2 \&$ Fig. 2).

Table 2. Antibacterial activity of $S$ bucharica leaves in Methanol extraction

\begin{tabular}{|c|c|}
\hline Microbs (Bacteria) & Inhibition Zone (mm) \\
\hline E. coli & $\mathbf{3 0}$ \\
\hline S. aureus & $\mathbf{4 5}$ \\
\hline S. typhi & $\mathbf{2 5}$ \\
\hline B. subtilis & $\mathbf{3 3}$ \\
\hline P. aeruginosa & $\mathbf{2 4}$ \\
\hline Mean & $\mathbf{3 1 . 4}$ \\
\hline
\end{tabular}




\section{Inhibition Zone ( $\mathrm{mm})$}

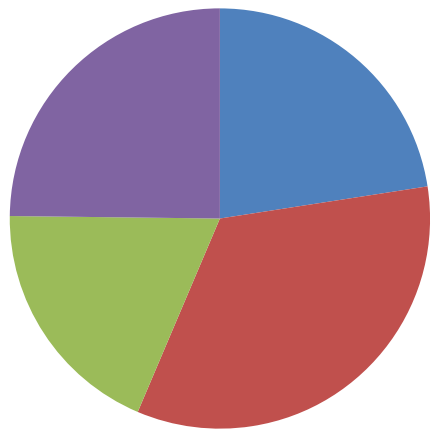

E. coli

S. aureus

S. typhi

B. subtilis

P. aeruginosa

\section{Figure 2. Inhibition zone of S. bucharica}

The whole plant of $T$. serpyllum was tested against the several types of Gram +ve and Gram -ve Bacteria i.e S. typhae, S. aureus, S. albus, B. subtilis and E.coli. Out of these Bacteria the $E$. coli has the highest inhibition zone and the S. subtilis has the lowest inhibition zone. The figure shown in the (Table $3 \&$ Fig. 3). The mean value is $23.8 \%$ of all microbes.

Table 3. Antimicrobial activity of $T$. serpyllum (whole plant) in Methanol concentration

\begin{tabular}{|c|c|}
\hline Microbes (Bacteria) & Inhibition zone (mm) \\
\hline S. typhae & $\mathbf{1 8}$ \\
\hline S. aureus & $\mathbf{2 1}$ \\
\hline S. albus & $\mathbf{2 0}$ \\
\hline B. subtilis & $\mathbf{2 2}$ \\
\hline E. coli & $\mathbf{3 8}$ \\
\hline Mean & $\mathbf{2 3 . 8}$ \\
\hline
\end{tabular}

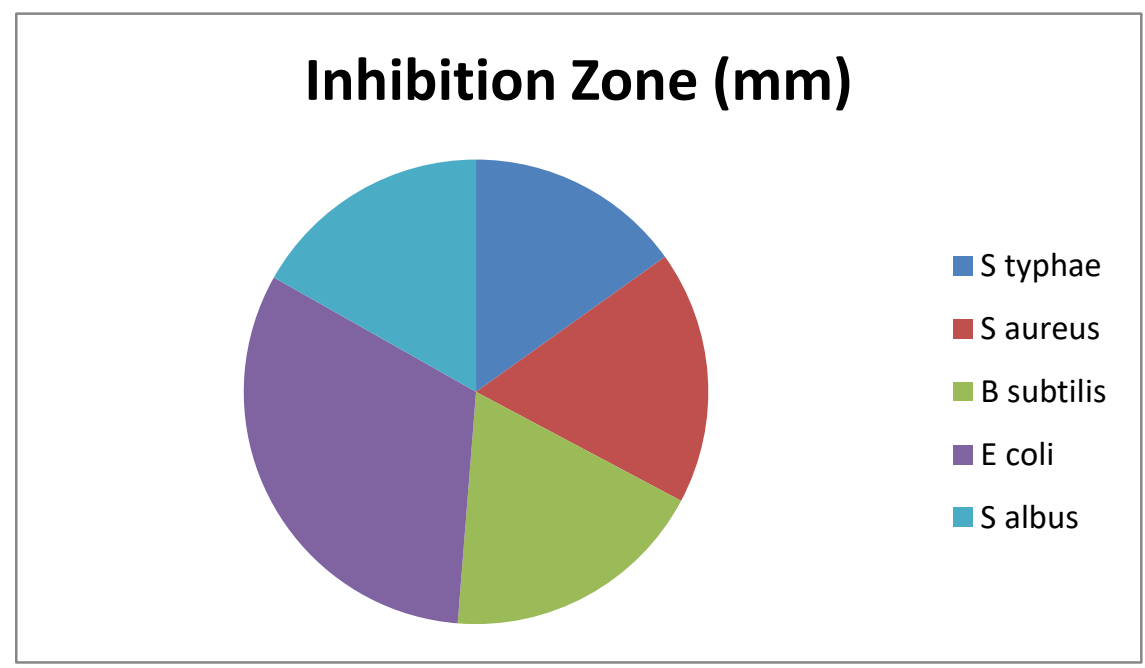

Figure 3. Inhibition zone of T. serpyllum

\section{Discussion}

Plants contain variant contents in shape of secondary metabolites. Especially, medicinal plants are highly rich with constituents of antimicrobial activities particularly anti bacteria. The selected area 
for this research is Shudden, Mazo, Tehsil Nana Sab area, Pishin. For this aforementioned area, I selected three plants, T. serpylum, S. bucharica and $B$. balochistanica, which are highly used for medicinal purposes. After conducting research, it found that they have highly antibacterial property.

The present data obviously shows that $B$. balochistanica roots are comparably more fruitful metabolites in huge amount like as phenols, against all test plant species [21]. B. balochistanica have optional vitaminns, alkaloids, carotinoides and flavonoids [22]. The leaves of $B$. balochistanica have Due to these parts shows the immense impacts low impact against the Bacteria as contrast with roots. B. balochistanica has the most elevated inhibitory zone against the $S$. pyogenes which is $81 \%$ yet the least for $P$. aerogenosa.

S.bucharica possesses antimicrobial action. Unmistakable bacterial substance containing both Gram negative and Gram positive living things were used for the appraisal of antibacterial development. The result showed that concentrates from $S$. bucharica (leaves) had antibacterial activity, regardless of the way that they differ basically in their activities against attempted smaller than usual living creatures. S. bucharica plant has the most extreme hindrance zone against the S.aureus and the base restraint zone against the $P$. aerogenosa [23].

T. serpyllum grown in different geographic locations worldwide produced essential oils that exhibited antimicrobial activity against several microorganisms [24-26]. The current study shows the entire plants of $T$. serpyllum was tried against the few kinds of both Gram +ve and gram -ve S. typhae, $S$. aureus, S. albus, B. subtilis and E. coli. Out of these bacteria $E$. coli has the most elevated hindrance zone and the $S$. subtilis has the least restraint zone.

\section{Conclusion}

These plants have highly rich substances against bacteria. Either T. serpyllum or $B$. balochistanica and $S$. bachurica are the plants which have significant amounts of contents against the subjected species of bacteria. T. seriphylum has highly antimicrobial activity against $E$. coli but lowest activity against $S$. aureus. As well as $S$. bachurica has highest function against $S$. aureus but least for P.aeruginosa. Among these, $B$. balochistanica is also immence impact against bacteria.

\section{Authors' contributions}

Conceived and designed the experiments: SU Rehman, Performed the experiments: M Idrees, Analyzed the data: M Idrees \& MU Rehman, Contributed reagents/ materials/ analysis tools: SK Leghari, KU Rehman, AKK Achakzai, B Zareen, BS Zaman \& A Malik, Wrote the paper: M Idrees \& SU Rehman.

\section{References}

1. Uddin S \& Safdar LB (2021). Green Synthesis of Nickel Oxide Nanoparticles from Berberis balochistanica Stem for Investigating Bioactivities. MDPI Mol 26: 1548.

2. Farnsworth NR \& Soejarto DD (1991). Global importance of medicinal plants. In: Akerele O, Heywood V, Synge H (Eds.). The Conservation of Medicinal Plants. Cambridge University Press, Cambridge. pp. 25-52.

3. Bhalodia NR \& Shukla VJ (2011). Antibacterial and antifungal activities from leaf extracts of Cassia fistula 1: An ethnomedicinal plant. $J$ of Adv Pharma Technol \& Res 2: 104-109.

4. Pushpa H \& Purushothama KB (2010). Antimicrobial activity of Lyophyllum decastes an edible wild mushroom. World $J$ of Agricul Sci 6(5): 506-509.

5. 4. Kumar AO, Mutyala NL \& Raja RKG (2010). Antibacterial Evaluation of Snake Weed (Euphorbia hirta L.). Inter $J$ of Pharm Tech Res 2: 1383-1385.

6. Suneetha G \& Ravi V (2013). Antimicrobial Activity of Andrographis paniculata Flower Extracts. Inter $J$ of Res and Rev in Pharma and Appl Sci 2: 604610.

7. Deepak S, Pawar A \& Shinde P (2014). Study of antioxidant and antimicrobial activities of Andrographis paniculate. Asian J of Plant Sci and Res 4: 31-41.

8. Rahman SA, Abd-Ellatif SA, Deraz SF \& 
Khalil AA (2011). Antibacterial activity of some wild medicinal plants collected from western Mediterranean coast, Egypt: Natural alternatives for infectious disease treatment. Afr J of Biotechnol 10: 1073310743.

9. Martins AP, Salgueiro L, Goncalves MJ, Proencacunha V, Vila R, Canigueral S \& Mazzoni V (2001). Essential oil composition and antimicrobial activity of three Zingiberaceae from $S$. tomeeprincipe, $J$ of Planta Medica 67: 580-584.

10. Din SU (2021). Green synthesis of nickel oxide nanoparticles using leaf extract of Berberis balochistanica: Characterization, and diverse biologicalapplications.10.1002/jemt.2375 6.

11. Alamgeer et al. (2018). Traditional medicinal plants used for respiratory disorders in Pakistan: a review of the ethnomedicinal and pharmacological evidence. Pub by Chin Med 13020-018-0204-y

12. Nadir M et al. (2014). First GC-MS study of essential oil from salvia bucharica. 0009-3130/14/5001-0144 2014 Springer Science+Business Media New York

13. Erci F \& Torlak E (2019). Antimicrobial and antibiofilm activity of green synthesized silver nanoparticles by using aqueous leaf extract of Thymus serpyllum. Sakarya Uni J of Sci 23(3): 333-339.

14. Ikram M, Jan G, Khan SD, Jan FG, Ullah A, Shaheen S, Ijaz F, Rehman S, Bahadar S, Ziaulhaq, Ali A \& Iqbal Z (2015). Antimicrobial Activity and Phytochemical Screening of Artemisia annua L. and Millotus philippensis (Lam.) Mull. Arg. Leaves. Am-Eur J Agric \& Environ Sci 15(12): 2437-2441.

15. Zaidi MA \& Crow SA (2012). Cytotxicity of Four Medicinal Plants of Pakistan. Pak J Bot 44(SI): 395-397.

16. Shinwari Z.K (2010). Medicinal plants research in Pakistan. J Med Pl Res 4(3): 161-176.

17. Doughari JH (2006). Antimicrobial Activity of Tamarindus indica Linn. Trop J of Pharma Res 5: 597-603.
18. Lupoae M, Coprean D, Dinică R, Lupoae P, Gurau G \& Bahrim G (2013). Antimicrobial Activity of Extracts of Wild Garlic (Allium ursinum) from Romanian Spontaneous Flora. 14(4): 221-227.

19. Pervez $S$ et al. (2019). Antimicrobial and antioxidant potential of berberisinol, a new flavone from Berberis baluchistanica. DOI 10.1007/s10600-01902660-4

20. Javid T, Adnan M, Tariq A, Akhtar B, Ullah R, Abd NM \& Salam E (2015). Antimicrobial activity of three medicinal plants (Artemisia indica, Medicago falcate and Tecoma stans). Afr J of Trad, Compl and Alter Med 12(3).

21. Pervez S, Saeed M, Ali MS, Fatima I, Khan H \& Ullah I (2019). Antimicrobial and Antioxidant Potential of Berberisinol, a New Flavone from B. baluchistanica. Chem Nat Compd 55: 247-251.

22. Kakar MA, Jabeen H, Kakar S, AlKahraman Y \& Shafee M (2012). Screening of antibacterial activity of four medicinal plants of Balochistan-Pakistan. Pak J Bot 44: 245-250.

23. Khan AR \& Khan MJ (2021). Invitro Antileishmanial, Cytotoxic and Antioxidant activities of Salvia bucharica leaves extract and its fractions. Inter $J$ of Basic \& Appl Sci 13(4).

24. Ahmad AM, Khokhar I, Ahmad I, Kashmiri MA, Adnan A \& Ahmad M (2006). Study of antimicrobial activity and composition by $\mathrm{gc} / \mathrm{ms}$ spectroscopic analysis of the essential oil of Thymus serphyllum. Inter J Food Safety 5: 56-60.

25. Eteghad SS, Mirzaei H, Pour SF \& Kahnamui S (2009). Inhibitory effects of endemic Thymus vulgaris and Mentha piperita essential oils on E. coli 0157:H7. Res J Biol Sci 4: 340-344.

26. Imelouane BH, Amhamdi JP, Wathelet M, Ankit $\mathrm{K}$ and Khedid \& El Bachiri A (2009). Chemical composition of the essential oil of thyme (Thymus vulgaris) from Eastern Morocco. Inter J Agric Biol 11: 205-208. 